\title{
Analysis of the resistance to fire of solid concrete boards with polypropylene microfibers and long curing time
}

\author{
Gustavo Manica (Main Author) \\ University of Vale do Rio dos Sinos, Civil Engineering Department \\ 93022-750, São Leopoldo (Brazil) \\ gustavomanica@unisinos.br
}

\section{Fabrício Bolina}

University of Vale do Rio dos Sinos, Civil Engineering Department

93022-750, São Leopoldo (Brazil)

fabriciolb@unisinos.br

Bernardo Tutikian (Corresponding Author)

University of Vale do Rio dos Sinos, Civil Engineering Department

93022-750, São Leopoldo (Brazil)

bftutikian@unisinos.br

\section{Matheus Valadares}

University of Vale do Rio dos Sinos, Civil Engineering Department

93022-750, São Leopoldo (Brazil)

matheusvaladares29@hotmail.com

Manuscript Code: 1559

Date of Acceptance/Reception: 25.11.2019/25.07.2019

DOI: 10.7764/RDLC.18.3.595

\begin{abstract}
Reinforced concrete elements with long curing ages tend not to present spalling when subjected to high temperatures since heat transfer in concrete is influenced mostly by the materials constituting its composition. Polypropylene microfiber-reinforced concrete presents more porosity and higher thermal insulation as the fibers melt when exposed to high temperatures. Therefore, this study aimed to assess the influence of the addition of polypropylene microfibers on the resistance to fire of reinforced concrete boards. The mechanical tests required crafting 18 boards and 3 walls in real scale, which measured $3.15 \times 3.00 \mathrm{~m}$. The analysis comprised 3 types of systems, being the reference reinforced concrete and the concretes with polypropylene microfiber ratios of $0.97 \mathrm{~kg} / \mathrm{m}^{3}$ and $1.94 \mathrm{~kg} / \mathrm{m}^{3}$. Were extract 18 specimens for the axial compression test. The fire test was performed in a vertical furnace under the ISO 834 curve. None of the 3 walls displayed spalling and the boards with higher microfiber ratios presented better fire performance, with smaller maximum displacements. The wall with $1.94 \mathrm{~kg} / \mathrm{m}^{3}$ microfiber ratio obtained a gain of 23.5 min in thermal insulation compared to the reference reinforced concrete wall. It was also perceived that the incorporation of polypropylene microfibers in the concrete reduces its compressive strength.
\end{abstract}

Keywords: Solid reinforced concrete boards, Resistance to fire, Wall system, Polypropylene microfiber, Heat transfer mechanism.

\section{Introduction}

Harmful agents present in the environment affect reinforced concrete, resulting in physicochemical transformations. Concrete durability loss can occur due to physical, mechanical or chemical mechanisms of deterioration (Neville \& Brooks, 2010; Pacheco, Christ, Quinino, \& Tutikian, 2018). Every harmful environment is subjected to assorted manifestations that degrade the mechanical strength of the structure over time (Fernandes, Christ, \& Quinino, 2016; Mehta \& Monteiro, 2014). The exposure of concrete to high temperatures brings about the loss of mechanical properties and compromises user safety (Bolina, Baques, Tutikian, \& Rodrigues, 2018), therefore fire resistance must be considered (Garay, Figueroa, Pfenniger, \& Larenas, 2017).

The fire performance of concrete structures can be assessed by measuring the spalling on the section and the mechanical strength loss (Gil et al., 2017; Ollivier \& Vichot, 2014). When concrete is exposed to fire, it becomes susceptible to explosive spalling, mainly between temperatures of $100^{\circ} \mathrm{C}$ and $400^{\circ} \mathrm{C}$ (Castro, Tiba, \& Pandolfelli, 2017). However, studies that have been conducted to analyze this phenomenon have focused on small specimens, like Hager (2013), Ali, Dinkha, \& Haido (2017), and Ozawa \& Morimoto (2014). It is known, though, that these tests cannot be conclusive with regards to the overall performance of a structural system, thus a full-scale study is needed to analyze the behavior of the structure. 
According to Jameran, Ibrahim, Yazan, \& Rahim (2015), explosive spalling is a threat to buildings and other concrete structures because it is caused by the absence of voids that relieve the pressure accumulated within the structure. The internal pressure caused by the water vapor contained in the element, along with the formation of cracks and the system's transverse displacement, can contribute to spalling (Wang, Barber, Johnson, \& Hui, 2013). This pressure is related to the small permeability of concrete that limits the ability to eliminate moisture during the heating, therefore resulting in greater internal stresses from the pore-pressure phenomenon (Gil, Fernandes, Bolina, \& Tutikian, 2018).

As the surface of the piece gets heated, the flow of heat that occurs within the element gradually increases the temperature of the solid skeleton, consequently heating the water in the pores in the process of heat transfer. Vapor tends to migrate to the surface of concrete causing pressure accumulation (Bolina, 2016). Spalling takes place when the internal pressure surpasses the tensile strength of concrete (Dwaikat \& Kodur, 2010), resulting in the direct exposure of reinforcements to fire, reduction of transverse section and loss of thermal insulation of the element (Mindeguia, Pimienta, Noumowé, \& Kanema, 2010; Silva, 2012).

As per Phan (2008), the addition of polypropylene fibers causes a significant reduction of concrete pore pressure, which may even prevent spalling because polypropylene fibers reach their fusion point at $170^{\circ} \mathrm{C}$. A permeable mesh begins to form at this temperature, which allows the percolation of water and vapor in the structure. This new mesh of pores helps to reduce internal pressure and can therefore eliminate explosive spalling (Castro et al., 2017).

Due to the need for water in liquid state or vapor to make pore pressure possible, spalling can be less intense or even absent in concretes with longer curing ages since cement hydration takes the water available in the pores, hindering the increase of internal pressure. After 90 days of curing of concrete prototypes, no spalling was noted on the structure, so the phenomenon can be disregarded at long curing ages (Ollivier \& Vichot, 2014).

For concrete with long curing time, the thermal insulation of the structure is affected mostly by the thermal properties of its constituting materials as there is no loss of section due to spalling. Thus, the voids generated when polypropylene fibers melt exert influence on the mechanism of heat transfer and absorption because of the air present in the pores, altering the thermal properties (Sacht, 2008).

The transfer of heat from the warm atmosphere to the element is ruled by laws of convection, radiation and conduction (Dwaikat \& Kodur, 2010), linked to internal or external thermal actions. The external thermal actions come from the room on fire and excite the element with hot gases mainly through the mechanisms of transfer by convection and radiation (Britez, 2011). The convective heat flow is proportional to the difference of temperature from the currents emanating from the fire, and the radiant heat flow is transferred to the structure by the heat absorption capacity of concrete, penetrating the piece mostly though conduction (Kim, Youm, \& Reda Taha, 2014). For Britez (2011), this mechanism of conduction in concrete results from conductibility, diffusivity and specific heat capacity, since these properties relate to the porosity of the material.

According to Kim, Jeon, \& Lee (2012), thermal conductivity of concrete with low density, namely, with more pores, is lower than that of normal concrete. Since the thermal conductivity of air is lower than that of the cement paste (Neville, 2011), concrete with more voids presents lower conductivity and, due to its low density and thermal insulation, it attains greater resistance to fire (Gabrich, 2008). Considering the cement paste degree of hydration, though, the pores may not be filled solely with air as they could be filled with water and water vapor as well. Filling these pores with water can increase the conductivity of concrete compared to those filled with air, because the conductivity of water is greater than that of air. However, even with the saturation of pores, the conductivity of the system is still going to be lower than that of concrete without these pores (Neville, 2011). Therefore, the pores generated by melting polypropylene fibers, saturated or not, yield lower conductivity.

In this scenario, this study assessed the resistance to fire of reinforced concrete boards in real scale, with long curing age of 3 years and 6 months and ratios of 0.97 and $1.94 \mathrm{~kg} / \mathrm{m}^{3}$ of polypropylene microfibers, besides the reference sample with no fibers.

Methodology

To implement this study, solid reinforced concrete boards were built with dimensions of $3.15 \times 1.00 \mathrm{~m}$ and $0.1 \mathrm{~m}$ of thickness. Each test required the use of three concrete boards to make up a wall with dimensions of $3.15 \times 3.00 \mathrm{~m}$. The 9 boards summed up a set of 3 walls, whereas T1 had no addition of polypropylene microfibers, T2 had $0.97 \mathrm{~kg} / \mathrm{m}^{3}$ of 
microfibers and T3 had $1.94 \mathrm{~kg} / \mathrm{m}^{3}$ of microfibers, as per Table 1 . The boards were instrumented to measure displacement and thermal insulation.

Table 2 presents the characteristics of the polypropylene microfiber, while Table 3 presents the unit composition of the concretes.

\begin{tabular}{ll}
\multicolumn{2}{c}{ Table 1. Microfiber ratio. } \\
\hline Type & $\begin{array}{l}\text { Ratio } \\
\left(\mathrm{kg} / \mathrm{m}^{3}\right)\end{array}$ \\
\hline T1 & 0 \\
T2 & 0.97 \\
T3 & 1.940 \\
\hline Source: elaborated by the authors.
\end{tabular}

Source: elaborated by the authors.

\begin{tabular}{ll}
\multicolumn{2}{c}{ Table 2. Microfiber characteristics. } \\
\hline Characteristic & Microfiber \\
\hline Composition & Polypropylene \\
Length & $12 \mathrm{~mm}$ \\
Specific gravity & $910 \mathrm{~kg} / \mathrm{m}^{3}$ \\
Elastic modulus & $4 \mathrm{GPa}$ \\
Tensile strength & $620 \mathrm{MPa}$ \\
Alkaline resistance & High \\
Color & White \\
Shape & Monofilament \\
\hline Source: elaborated by the authors.
\end{tabular}

Source: elaborated by the authors.

\begin{tabular}{ll}
\multicolumn{2}{c}{ Table 3. Amount of materials. } \\
\hline Description & $\begin{array}{l}\text { Amount } \\
\left(\mathrm{kg} / \mathrm{m}^{3}\right)\end{array}$ \\
\hline Cement & 350 \\
Fine sand & 273 \\
Regular sand & 637 \\
Gravel & 952 \\
Superplasticizer & 2.2 \\
Water & 187 \\
\hline \multicolumn{2}{l}{ Source: elaborated by the authors. }
\end{tabular}

High early strength Portland cement with specific gravity of $3120 \mathrm{~kg} / \mathrm{m}^{3}$ was used. The admixture was a synthetic superplasticizer based on polycarboxylates with density of $1120 \mathrm{~kg} / \mathrm{m}^{3}$. The steel used to craft the pieces was ribbed and had $500 \mathrm{MPa}$ of yield strength, concealed by diameters of $5.00 \mathrm{~mm}, 8.00 \mathrm{~mm}$ and $12.5 \mathrm{~mm}$. The maximum fine sand diameter was $0.3 \mathrm{~mm}$, the regular sand was $4.75 \mathrm{~mm}$ and the gravel was $9.5 \mathrm{~mm}$.

In order to simulate the real-world applicability conditions of these elements, the reinforced concrete boards had a curing time of approximate 3 years and 6 moths, taking into consideration that a fire hardly occurs in less aged buildings.

The compressive strength test specimens were extracted from the boards with a water-cooled extractor with diamond core drill. During that procedure, 2 specimens were extracted from each board, totalizing 18 samples to increase result reliability. The drilling on those spots did not compromise the fire resistance test because that part of the board was not exposed to fire, owing to the length of the vertical furnace being shorter than the sample.

After the extraction, the specimens were rectified and then subjected to the compressive test established by ASTM C39/C39M (2018).

The fire resistance tests were performed in the itt Performance technological institute, at University of Vale do Rio dos Sinos, Brazil. The concrete boards were attached to a movable metal frame that measured $3.15 \times 3.00 \mathrm{~m}$. The boards were cured on the frame and, on the test date, they were affixed to the vertical furnace, whose fire exposure area was $2.5 \times 2.5 \mathrm{~m}$, without gaps to ensure the internal pressure during the test. The furnace followed the standard heating curve set by ISO 834-1 (1999) and was powered by gas burners.

The system sealing and the union of the boards relied on the use of a fire resistant sealant as a means to preserve airtightness and thermal insulation. A ceramic fiber blanket was used to cover the drilling to ensure no interference with the wall result. Figure $1 \mathrm{a}$ depicts the vertical furnace at work and Figure $1 \mathrm{~b}$ shows the wall attached to the furnace.

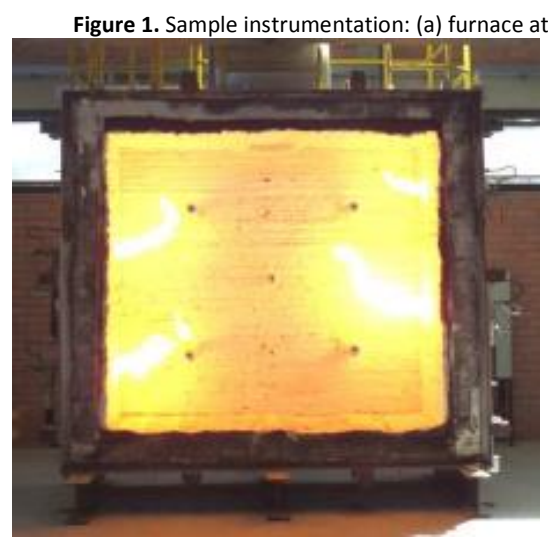

(a)

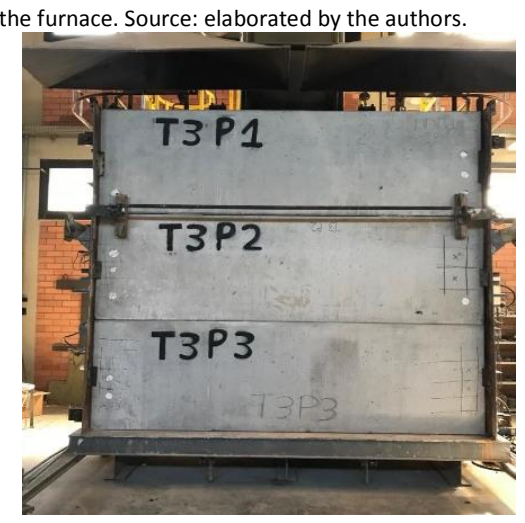

(b) 
The test method followed ASTM E119 (2018). Throughout the test, three criteria were analyzed: (a) thermal insulation, (b) air and smoke-tightness, and (c) structural stability. The fire resistance rating was then determined based on these criteria. Whenever one of these requirements was not met, the test would be interrupted, except for thermal insulation. With the aid of a thermographic camera, it was possible to identify cracks on the external surface of the samples and points most susceptible to loss of airtightness.

To assess thermal insulation, 5 thermocouples were placed on the surface of the walls that was not exposed to fire. The sample is rejected under this requirement when the arithmetic average of external temperature surpasses $140^{\circ} \mathrm{C}$ plus room temperature, or, at each thermocouple, $180^{\circ} \mathrm{C}$ plus room temperature, whichever occurs first. Regarding airtightness, fail occurs when there is a crack that allows the passing of hot gases and smoke, setting the cotton wad ablaze. The structural stability requirement refers to the total or partial collapse of the samples. The deformations were checked every 10 minutes with the aid of a laser distance measurer placed at the center of the wall.

The sample was monitored continuously by type $\mathrm{K}$ thermocouples with diameter of $1.5 \mathrm{~mm}$ on the fire-exposed surface, and type $T$ thermocouples with diameter of $0.7 \mathrm{~mm}$ on the surface that was not exposed to fire.

Results and discussion

Figure 2 depicts the compressive strength results of the specimens extracted before the fire resistance test.

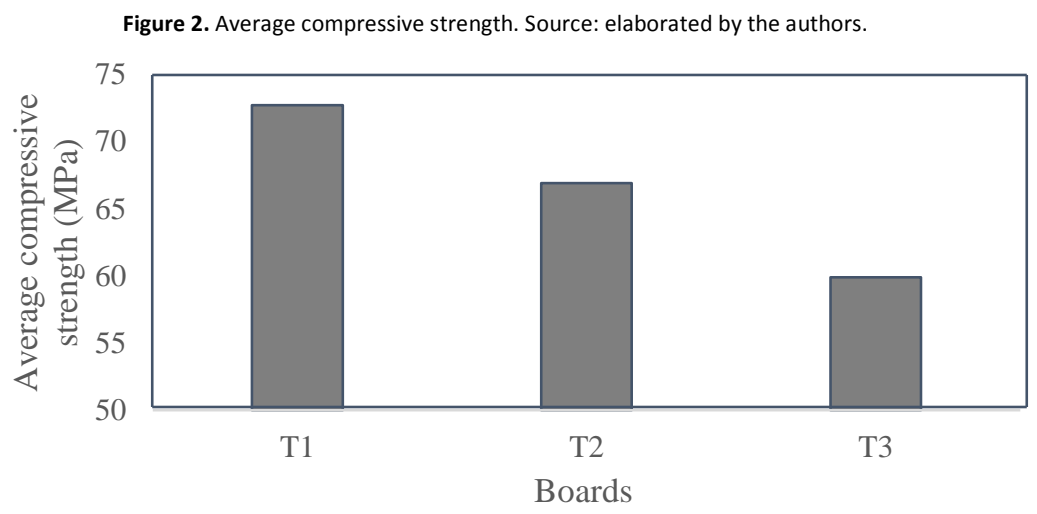

It should be noted that there was an attempt to extract the specimens from the boards after the exposure to high temperatures, but it was not possible due to the mechanical strength loss of concrete. Nevertheless, Jameran et al. (2015) suggests that compressive strength reduces when fiber-reinforced concrete is exposed to temperatures of $400^{\circ} \mathrm{C}$.

The use of microfiber added to the plates contributed to the drop in compressive strength of the material, stating that this polymer benefits only to minimize the risk of plastic cracking. The fiber occupies the space that was previously occupied by solid components, generating more breaking points. Therefore, the higher the microfiber content in the mixture, the lower the compressive strength due to non-structural function of this model.

All boards were exposed to fire for 240 minutes. None of the three systems that were tested presented spalling, result that was influenced by the long curing age of the concrete boards. Another plausible explanation for the absence of this phenomenon may be related to the pressure relief provided by the significant difference between porosities of concrete with and without the addition of polypropylene microfibers, due to the exposure to high temperature and the consequent total degradation of the fibers (Castro et al., 2017).

With more pores in concrete, the accumulation of pressure in these voids, resulting from the migration of water and vapor by the structure due to the gradual heating of its transverse section, was not effective enough to cause spalling (Phan, 2008), as the internal pressure did not exceed the tensile strength of concrete (Dwaikat \& Kodur, 2010). Without explosive spalling, there was no loss of section, fact that could influence fire performance negatively.

Table 4 presents the control, during the tests, of thermal insulation, airtightness and mechanical strength requirements set by the standard, along with the displacements at the center of the samples. Figure 3 presents the temperature of the five thermocouples arranged on the unexposed face of each wall. 
Table 4. Comparison of fire resistance tests. Source: elaborated by the authors.

\begin{tabular}{cccccc}
\hline Wall & $\begin{array}{c}\text { Microfiber } \\
\text { ratio }\left(\mathrm{kg} / \mathrm{m}^{3}\right)\end{array}$ & $\begin{array}{c}\text { Thermal } \\
\text { insulation }(\mathrm{min})\end{array}$ & $\begin{array}{c}\text { Airtightness } \\
(\mathrm{min})\end{array}$ & $\begin{array}{c}\text { Structural } \\
\text { stability }\end{array}$ & $\begin{array}{c}\text { Maximum displacement } \\
\text { measured }(\mathrm{m})\end{array}$ \\
\hline T1 & 0 & 107.5 & 155 & Unaffected & 0.089 \\
T2 & 0.97 & 115 & 178 & Unaffected & 0.078 \\
T3 & 1.94 & 131 & 138 & Unaffected & 0.064 \\
\hline
\end{tabular}

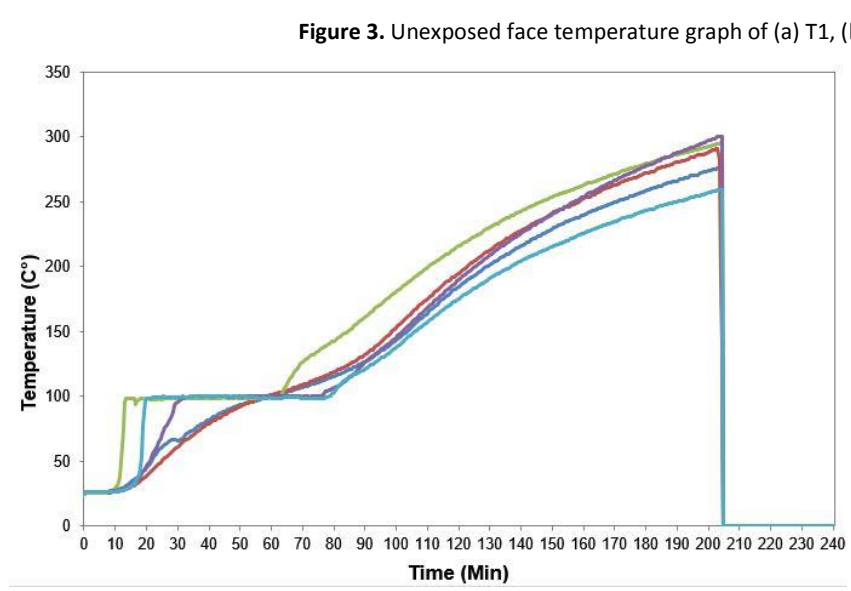

(a)

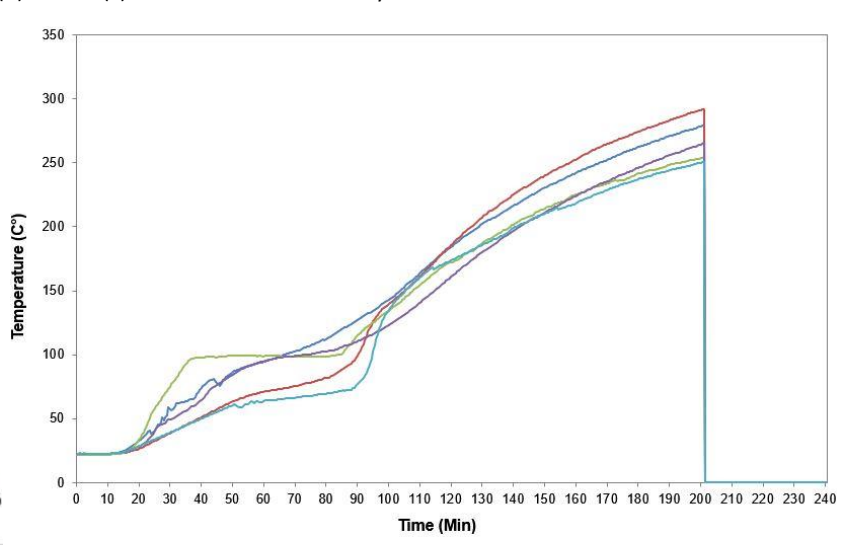

(b)

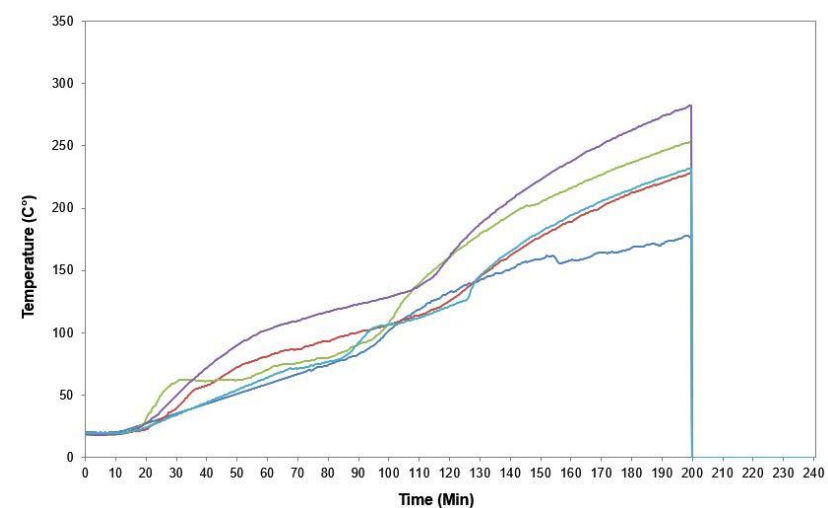

(c)

It should be noted that the spots that lost airtightness were only between the boards, that is, on the sealant. Since the goal of this study is to assess the fire performance of reinforced concrete boards, the airtightness results were ignored.

Moreover, as the polypropylene microfiber ratio increased, the system maintained its thermal insulation for a longer period of time. Sample T2, with microfiber ratio of $0.97 \mathrm{~kg} / \mathrm{m}^{3}$, had an increase of $7.5 \mathrm{~min}$ of thermal insulation compared to sample T1, with no addition of microfibers. Sample T3, with microfiber ratio of $1.94 \mathrm{~km} / \mathrm{m}^{3}$, presented a difference of 16 minutes compared to T2, and 23.5 min to T1.

The increased thermal insulation time was influenced by the smaller temperature gradient of the transverse section of concrete, so that the surface not exposed to fire was less heated. Increasing microfiber ratio led to the formation of voids in the structure, due to the melting of polypropylene at temperatures above $200^{\circ} \mathrm{C}$, as Castro et al. (2017) had noted.

Owing to the filling of these pores by air, which is a thermal insulator, and/or by water, depending on the degree of hydration of the cement paste, the density of concrete decreased. It was noted that, as the density of concrete decreased, so did the thermal conductivity, thereby reproducing the same phenomenon observed by Kim et al. (2012).

The maximum displacement was measured during the tests with higher microfiber ratio, result that can also be explained by the lower temperature gradients in the section. Because of these lower temperatures, thermal expansion tends to be minimized as heat transfer gets hindered. 
The reduced thermal expansion of the structure may contribute to smaller deformations on both heated and not heated surfaces, what can be observed in thermographic images, as depicted in Figure 4 and Figure 5 . These images were obtained at 30 minutes and at 60 minutes of testing, for each sample, allowing the visual comparison of the difference of temperature throughout the experiments.

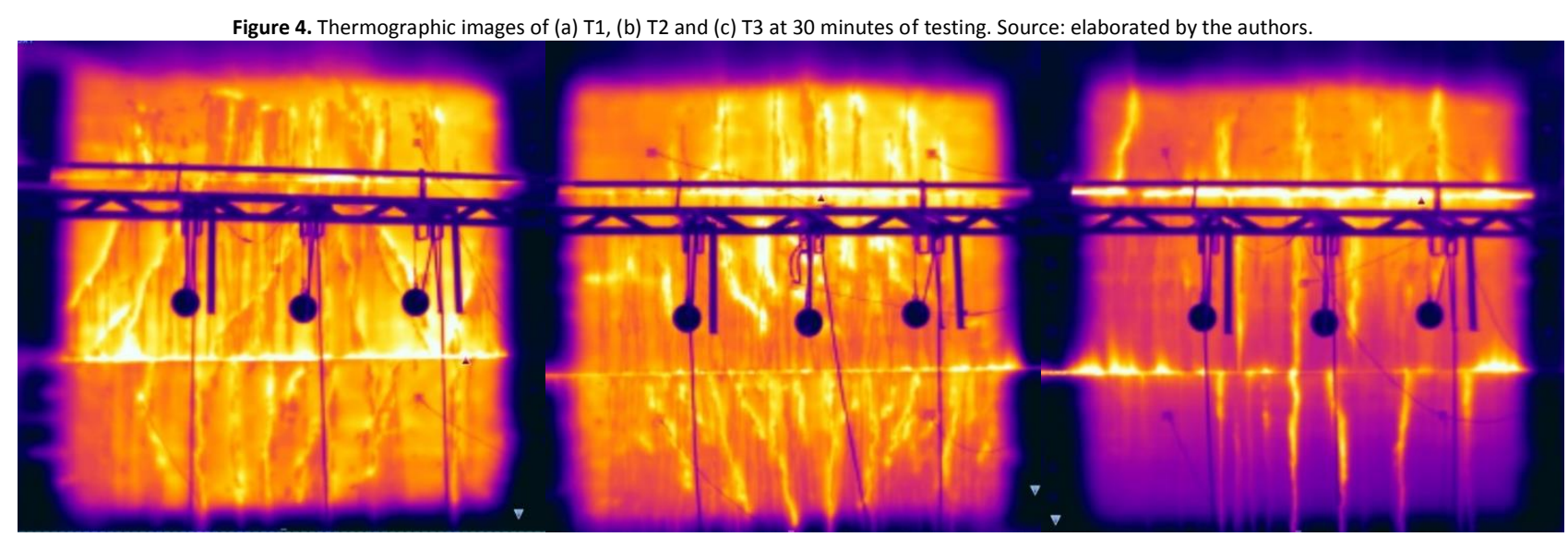

(a)

(b)

(c)

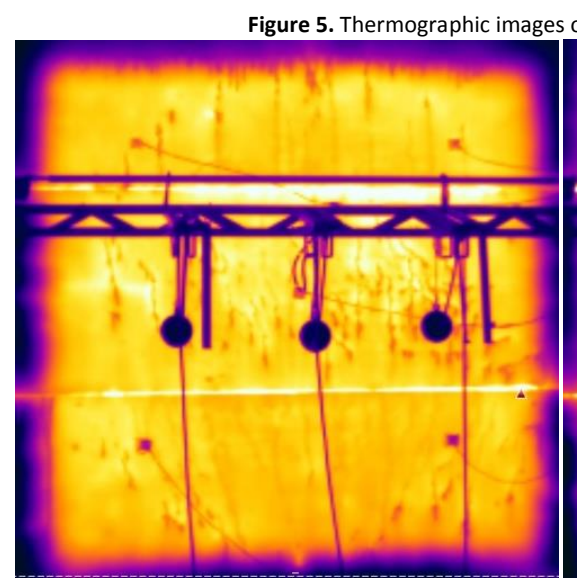

(a)

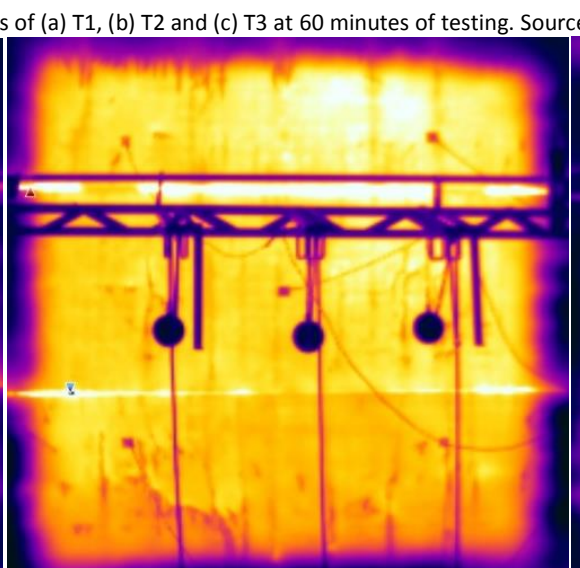

(b)

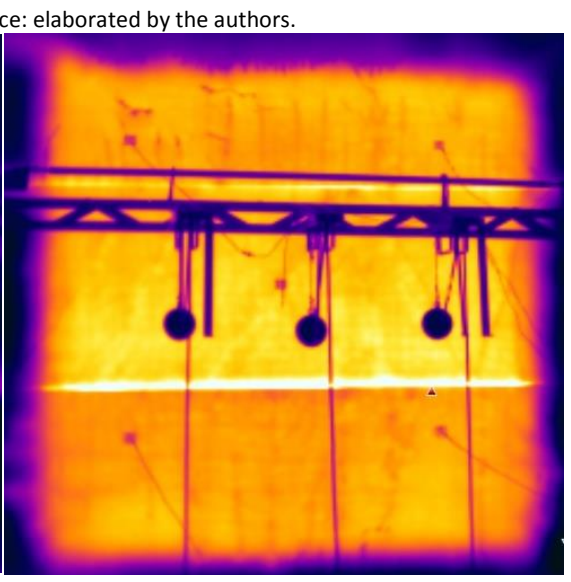

(c)

It is noteworthy that, at 30 minutes of testing, reference wall T1 presented the most cracks compared to the microfiberreinforced walls. The samples with more fibers yielded lower thermal gradient and less formation of cracks and passages for the entry of more heat.

The deformations generated bending moments and, in the beginning of heating, the shape of an arc directed towards the inside of the furnace and right after there is an inversion that makes the arc bend to the opposite side, phenomenon that is known as thermal bowing (Moura Correia, Rodrigues, \& Real, 2014). With more pores in the structure, owing to the melting of the polypropylene microfibers, internal stresses tend to be less effective due to pore pressure relief and lesser effectivity of thermal expansion. Thus, with less internal stresses, the concrete presented fewer deformations and smaller displacements as a result.

Conclusions

In agreement to the results obtained and discussed, the solid concrete boards containing a polypropylene microfiber ratio of approximately $1.94 \mathrm{~kg} / \mathrm{m}^{3}$ obtained the higher thermal insulation and the lower maximum displacement measured, suggesting that the presence of polypropylene microfiber is beneficial for concrete when exposed to fire. In contrast, the solid concrete boards without fiber showed the lowest thermal insulation and the highest maximum displacement measured.

By exposing microfiber-reinforced concrete to fire, it was possible to note the importance of polypropylene fibers to control internal pressure and hinder the mechanism of conduction heat transfer by reason of the total degradation of the microfibers when exposed to heating. Pressure relief, along with long curing age, prevented explosive spalling as 
more pores were formed in the structure and due to its greater mechanical strength and the lower amount of free water in the piece.

The hindered heat transfer was influenced by the increased amount of voids in the structure, considering that these were filled mostly with air due to the advanced hydration degree of the pieces. The thermal conductivity of concrete thus became smaller.

Therefore, the transverse section of concrete presented lower temperature gradient as the polypropylene microfibers were added to the system, considering that the surface not exposed to fire bore lower temperatures, sustaining the increased thermal insulation and, consequently, the higher fire resistance of the system.

The lower temperature gradient also collaborated to the minimization of the system's thermal expansion. With more pores in the solid concrete boards, internal stresses tend to be less effective due to pore pressure relief and lesser effectivity of thermal expansion. Therefore, the thermal bowing phenomenon had lower intensity and that smaller displacements could be measured as more microfibers were added to concrete.

It was also perceived that the incorporation of polypropylene microfibers in the concrete reduces its compressive strength, since it influences the structure at the material level. Thus, microfibers are recommended for sealing walls, as there is no need for them to resist loading, so this incorporation is beneficial for mixing. It was not possible to evaluate the influence of fibers on the compressive strength of the specimens after the fire test, as they were very degraded.

\section{References}

Ali, M. H., Dinkha, Y. Z., \& Haido, J. H. (2017). Mechanical properties and spalling at elevated temperature of high performance concrete made with reactive and waste inert powders. Engineering Science and Technology, an International Journal, 20(2), 536-541. doi:10.1016/j.jestch.2016.12.004

ASTM C39/C39M. Standard Test Method for Compressive Strength of Cylindrical Concrete Specimens (2018). American Society for Testing and Materials (ASTM).

ASTM E119. ASTM E119 - 18ce1 - Standard Test Methods for Fire Tests of Building Construction and Materials (2018). American Society for Testing and Materials (ASTM).

Bolina, F. L. (2016). Avaliação experimental da influência dos requisitos de durabilidade na segurança contra incêndio de protótipos de pilares préfabricados de concreto armado (Unpublished master's thesis). University of Vale do Rio dos Sinos, São Leopoldo, Brazil.

Bolina, F. L., Baques, B., Tutikian, B. F., \& Rodrigues, J. P. C. (2018). Analysis of the assessment methods of reinforced concrete beams in fire conditions proposed by NBR 15200. Revista IBRACON de Estruturas e Materiais, 11(6), 1308-1325. doi:10.1590/s1983-41952018000600008

Britez, C. A. (2011). Avaliação de pilares de concreto armado colorido de alta resistência, submetidos a elevadas temperaturas (PhD thesis). University of São Paulo, São Paulo, Brazil. doi:10.11606/T.3.2011.tde-31052011-170216

Castro, A. L. de, Tiba, P. R. T., \& Pandolfelli, V. C. (2017). Fibras de polipropileno e sua influência no comportamento de concretos expostos a altas temperaturas: revisão. Cerâmica, 57(341), 22-31. doi:10.1590/s0366-69132011000100003

Dwaikat, M. B., \& Kodur, V. K. R. (2010). Fire induced spalling in high strength concrete beams. Fire Technology, 46(1), 251-274. doi:10.1007/s10694009-0088-6

Fernandes B., Christ R., Quinino U., T. B. (2016). Análisis de concretos con no Conformidades: efectos de larga duración. Revista ALCONPAT, 6(3), 261270. doi:10.21041/ra.v6i3.154

Gabrich, M. F. (2008). Estudo da influência das adições minerais no comportamento do concreto sob a ação do fogo (Unpublished master's thesis). Federal University of Minas Gerais, Belo Horizonte, Brazil.

Garay, R. M., Figueroa, W., Pfenniger, F., \& Larenas, J. (2017). Project shelter, Part 1: Fire resistance and thermal insulation. Revista de la Construcción, 16(2), 339-354. doi:10.7764/rdlc.16.2.339

Gil, A. M., Fernandes, B., Bolina, F. L., \& Tutikian, B. F. (2018). Experimental analysis of the spalling phenomenon in precast reinforced concrete columns exposed to high temperatures. Revista IBRACON de Estruturas e Materiais, 11(4), 856-875. doi:10.1590/s1983-41952018000400011

Gil, A., Pacheco, F., Christ, R., Bolina, F., Khayat, K. H., \& Tutikian, B. (2017). Comparative study of concrete panels' fire resistance. ACI Materials Journal, 114(5), 755-762. doi:10.14359/51689715

Hager, I. (2013). Behaviour of cement concrete at high temperature. Bulletin of the Polish Academy of Sciences: Technical Sciences, 61(1). doi:10.2478/bpasts-2013-0013

ISO 834-1. Fire-resistance tests -- Elements of building construction -- Part 1: General requirements (1999). International Organization for Standardization (ISO). 
Jameran, A., Ibrahim, I. S., Yazan, S. H. S., \& Rahim, S. N. A. A. (2015). Mechanical properties of steel-polypropylene fibre reinforced concrete under elevated temperature. In Procedia Engineering, 125, 818-824. doi:10.1016/j.proeng.2015.11.146

Kim, H. K., Jeon, J. H., \& Lee, H. K. (2012). Workability, and mechanical, acoustic and thermal properties of lightweight aggregate concrete with a high volume of entrained air. Construction and Building Materials, 29, 193-200. doi:10.1016/j.conbuildmat.2011.08.067

Kim, J. J., Youm, K. S., \& Reda Taha, M. M. (2014). Extracting concrete thermal characteristics from temperature time history of rc column exposed to standard fire. Scientific World Journal, 2014, 10. doi:10.1155/2014/242806

Mehta, P. K., Monteiro, P. J. M. (2014). Concreto: Microestrutura, Propriedades e Materiais. 2th. Natal, Brazil: IBRACON.

Mindeguia, J. C., Pimienta, P., Noumowé, A., \& Kanema, M. (2010). Temperature, pore pressure and mass variation of concrete subjected to high temperature - Experimental and numerical discussion on spalling risk. Cement and Concrete Research, $40(3)$, 477-487. doi:10.1016/j.cemconres.2009.10.011

Moura Correia, A. J. P., Rodrigues, J. P. C., \& Real, P. V. (2014). Thermal bowing on steel columns embedded on walls under fire conditions. Fire Safety Journal, 67, 53-69. doi:10.1016/j.firesaf.2014.05.001

Neville, A. M. (2011). Properties of Concrete. 4th. London: Pitman Publishing.

Neville, A. M., \& Brooks, J. (2010). Concrete Technology. 2th. Canada: Building and Environment.

Ollivier J.; Vichot A. (2014). Durabilidade do concreto - Bases científicas para a formulação de concretos duráveis de acordo com o ambiente. 1th. Brazil: IBRACON.

Ozawa, M., \& Morimoto, H. (2014). Effects of various fibres on high-temperature spalling in high-performance concrete. Construction and Building Materials, 71, 83-92. doi:10.1016/j.conbuildmat.2014.07.068

Pacheco, F., Christ, R., Quinino, U., \& Tutikian, B. F. (2018). Effects of fiber hybridization in advanced cementitious composites durability in humid and aggressive environments. Revista Materia, 23(3). doi:10.1590/S1517-707620180003.0505

Phan, L. T. (2008). Pore pressure and explosive spalling in concrete. Materials and Structures, 41(10), 1623-1632. doi:10.1617/s11527-008-9353-2

Sacht, H. M. (2008). Painéis De Vedação De Concreto Moldados in Loco: Avaliação De Desempenho Térmico E Desenvolvimento De Concretos (Master's thesis). University of São Paulo, São Carlos, Brazil. 10.11606/D.18.2008.tde-17102008-114925

Silva, V. P. (2012). Projeto de estruturas de concreto em situação de incêndio. 1th. Brazil: Blucher.

Wang, G., Barber, D., Johnson, P., \& Hui, M. C. (2013). Fire safety provisions for aged concrete building structures. Procedia Engineering, $62,629-638$. doi:10.1016/j.proeng.2013.08.108 